\title{
The Key Elements of a Well-written Text: Discourse, Grammar and Lexis in a Foreign Language
}

\author{
Yongheng Wang \\ School of Foreign Languages, SWUN, Chengdu 610225, China \\ 1532698155@qq.com
}

Keywords: Foreign Language, Discourse, Grammar, Lexis, Well-written text.

\begin{abstract}
A well-written text is characterized by a well-structured discourse that is clearly linked with correct use of grammar and lexis. The lexis-grammatical system and the discourse pattern of a language are not too separate things, so the poor use of lexis-grammar often leads to bad discourse organization, which will disorient the reader from understanding what the writer of the text is intended to express to the reader. Therefore, in order to enable the language learner to have a clear understanding of a written-text or even produce a well-written text, the author of this essay explores why language teachers should make an effort in teaching students to learn to study its discourse, grammar and lexis in an EFL class and how.
\end{abstract}

\section{Introduction}

In order to have a clear understanding of a written text or even produce a well-writen text, teachers must help learners to understand what the key elements of a well-written text are: discourse, grammar and lexis. Teachers should put much emphasis on teaching students to learn to study its discourse, grammar and lexix carefully. The lexio-grammatical system and the discourse pattern of a language are not two separate things, and they are closely related to each other, so the poor use of lexio-grammar often leads to bad discourse orgnization, which will disorient the reader from understanding what the writter of the text is intended to express to the reader. So, discourse, grammar and lexis are closely correlated to each other. If there are problems in any of the three parts in a written text, the text can not be said to be a well-written one.

\section{Three Elements in a Well-Written Text}

\subsection{Discourse.}

Murcia \&Olsten [1] states a piece of discourse is an instance of spoken or written language that has describable internal relationships of form and meaning, for example, its words, struture, cohesion that relates coherenetly to an external communicative function or purpose and a given audience/interlocutors. McCarthy [2] holds a well-written text is characterized by a well-structured discourse that is clearly linked with the correct use of grammar and lexis. The poor grammtical and lexical knowledge, the poor organization of sentences and the poor organization of paragraphs will undoubtably disorient the reader from understand the text. If there are too many long sentences which non-sentences in a text are, it will be quite difficult for the reader to understand. We often come across some sentences that are too long and too difficult for us to find out its exact structure, which will possibly lead to misunderstanding of these sentences. After carefully studying them, we may find that they are actually incomplete sentences: there might be no subjects, no predicates, or inappropriate use of conjunctions. Inappropriate use of conjunctions creates difficulties for the reader in relating segments of texts to one another coherently. For example, if the writer did not know that the pronouns and the deitic words couldn't be used to refer across paragraph boundary execpt their referents are the topics of the preceding paragraph, what they produce will disorient the reader. 


\subsection{Grammar.}

Grammar may be roughly defined as the way a language manipulates and words or bits of words in order to form longer units of meaning. There is a set of rules which govern how units of meaning may be constructed in any language. We may say that a learner who knows grammar is the one who has mastered and can apply these rules to express him or herself in what would be considered acceptable language form [3]. There is a close link between grammar and discourse. Without rich and variable resourses of the the grammar, the construction of natural and sophisticated written text is impossible [4] (McCarthy,1991). Grammatcial errors will cause misunderstanding. We must try to use correct grammatical features to make the sentence or the texft cohesive, natural and sophisticated when writing in a second or foreign language.

I'll take following sentences as examples to see whether one could understand the correct use of grammar and how important it is to use the grammar in a correct way.

Sentence 1: Just got home from shopping to a message from my Dad.

Sentence 2: He wants to meet me for lunch on Sunday.

Sentence 3: He has roast beef, or salmon and new potatoes, at home, with Mum.

Sentence 4: She, too, is coming to see me tomorrow, apparently.

Sentence 5: I went around the corner for some cigarettes and came back to a phone message from Mum.

Sentence 6: As Dad sat down on the sofa, his face crumpled and tears began to splosh down his cheeks.

After reading Quirk's and Hopper's books about grammar, we know the major difference between Quick analysis and Hopper analysis is focused on verbs. From Quirk's “A university grammar of English" in 1973, we know he thinks the infinitive phrase as an adverbial. But when I analyze Sentences 2, 4 and 6, I find that it seems odd if the infinitive phrases in these sentences are analyzed as adverbials. This really confuses me. I'm still not sure whether "down his cheeks" in Sentence 6 functions as an adverbial or not in terms of Hopper's approach [5]. The first sentences in this task is not easy for a learner to analyze because there are three prepositional phrases put together and it's hard to judge whether "Just" is a subject or not.

Although teachers spend much effort explaining some features of grammar, students still fail to use them correctly, especially in spontaneous speech. But it doesn't mean that teachers can leave such rules out. B. Kachru [6] tells us that no matter whether the norm is native speaker or non-native speaker variety, no matter whether English is a foreign or a second language, two components of English must be taught and learnt without variation: the grammar and its core vocabulary. There may be embellishments in the way of local vocabulary and expressions, and there will certainly be great differences of pronunciation, but the grammar and vocabulary of English are taught and learnt virtually without variation around the world. So English teachers must spend some time on teaching grammar and vocabulary.

\subsection{Lexis.}

Oxford Advanced Learner's Dictionary of Current English (1984) defines lexis as the total number of words which with rules for combining them make up a language. Lexical items are also strongly associated with the structure of a written text. The vocabulary choice is just as discourse-sensitive as the grammatical choice that we talked above. If a text lacks lexical cohesion and discourse organization words, it cannot be a natural a successful text [2]. Thus, the learner has to learn to use proper vocabulary to make the sentence or the text cohesive and natural. The correct understanding and the use of some of the important hyponymy, collocation, idiom and euphemism is very important in language learning.

Hyponymy: Thornbury [7] (1997) defines hyponymy as different words but same word family or lexical field. Hyponymy, the relation between more specific(hyponymous) terms (e.g. cash, cheque) and less specific(superordinate) terms (e.g. money) is defined in terms of one-way rather than two-way entailment. Thus, cash or cheque entails money, but money does not entail cash or cheque,

e.g.: money: cash cheque family: child parents 
party: birthday party, wedding party, anniversary party

Collocation: Longman Dictionary of Contemporary English (1995) defines collocation as the way in which some words are often used together, or a particular combination of words in this way. Collocation is a marriage contract between words, and some words are more firmly to each other than others [8] (McCarthy, 1990). For exmaple, we often use make your dream come true instead of your dream get or turn true to express the same meaning. Here are some other fixed collocations we often use: afford the holiday, host a massive party, dream, see an end to, spend on, cast your mind back to. etc.

Idiom: Longman Dictionary of Contemporary English (1995) provides information concerning the idioms: "a group of words with a meaning of its own that is different from the meanings of each separate word put together." Usually, the meaning of the idiom can not be derived from the sum of its parts. For example, we can not get the meaning of "step on the grass", and "raining cats and dogs" if we simply translate them word by words. Just as we can not get the realing meaning of the idiom "bread the bank" if we only look at the meanings of each separate word which is put together "break", "the", "bank". Look at two other examples: build up a savings nest-egg, your money is in safe hand.

Euphemism: We know from the dictionary that the definition of euphemism is an example of the use of other mild, vague and indirect words or phrases in place of what is required by truth or accuracy. It is used to avoid saying certain things as well as to express them. Euphemism allows us to talk bout unpleasant things and neutralize teh unpleasantness, e.g. the subjects of death and dying, unemployment and criminality.

If we could have a good mastering of hyponymy, collocation, idiom and euphemism, we then could understand and even use them correctly in a text. Besides, register is also very important in language use. Register is a useful abstraction linking variations of language to variations of social context [9] (Gregory \&Carroll, 1978). The purpose of learning a foreign language is to be able to use it, so need to understand what register is and how it is closely related to our daily life. For example, when we come across a text in forms of an advertisement, three parameters of register which include field, tenor and mode help us to understand the advertisement better. Field is what the text is about and where it belongs --- subject matter, topic; tenor is who involved in the discourse --- the roles and relative power of speakers, writers and readers; mode is how the text is produced --- written of spoken, face-to-face, email, phone, etc. Learners ought to be trained to understand this kind of text, which will then enable them to have a better use of the target language they are learning.

\section{Summary}

In conclusion, discourse, grammar and lexis are closely related to each other. If there are any problems in any of the three parts in a written text, the text can not be said to be a well-written one. Therefore, language teachers should always keep in mind that these three can never be ignored in their teaching.

\section{References}

[1]. Murcia \&Olsten. Discourse and context in language teaching: a guide for language teachers. Cambridge: CUP pp, 252-256, 2000.

[2]. McCarthy, M \& Carter, R. Language as Discourse. New York: Longman Group Liminted. pp 276-284, 1994

[3]. Penny, Ur. Grammar Practice Activities: a practical guide for teachers. Cambridge: CUP. pp89-107, 1998

[4]. McCarthy, M. Discourse Analysis for Language Teachers. Cambridge: CUP. Pp314-326, 1991

[5]. Hopper, P.J. Discourse and category “verbs" in English. Lanuage Communication. 17/2pp93-102, 1995 
[6]. Kashrut, B. The other tongue: English across cultures. Urban and Chicago: University of Illinois Press. Pp157-173,1992

[7]. Scott Thornbury. About Language: Task for teachers of English. Cambridge: CUP. Pp313-319,1997

[8]. McCarthy, M Vocabulary. Oxford: OPU. Pp86-103, 1990

[9]. Gregory \& Carroll. Language and situation: language varieties and their social context. London: Routledge \& Kegan Paul Ltd. 1978 